\title{
Chemical Investigations of the Essential Oils of Some Artemisia species of Ethiopia
}

\author{
Mukul Chauhan \\ Department of chemistry, college of Natural and computational science, Ambo university, Ethiopia
}

\begin{abstract}
The compositions of the areal parts of essential oils of Artemisia abyssinica, A. absinthium (Ariti), and A. annua have been studied. The oils were examined by $G C, G C / M S,{ }^{1} H N M R$, and ${ }^{13} C N M R$ techniques.The total constituents of the oils 59\%, 56\%, and 44\% have been identified from A. abyssinica, A. absinthium(Ariti), and A. аппиа respectively. The major components were yomogi alcohol and artemisia alcohol acetate for $A$. abyssinica; camphor,davanone and chamazulene for A. absinthium and camphor for A. annua. Four compounds were isolated from A. abyssinica and A. absinthium and their structure were elucidated based on spectroscopic techniques.
\end{abstract}

Key words: Artemisia, A. absinthium ( Ariti), anisaldehyde reagent, chamazulene,essential oils, monoterpenes

\section{Introduction}

Artemisia is Annual or perennial herbs with strong aromatic leaves. The genus Artemisia is one of the largest genera in the tribe Anthemideae (Asteraceae) [2,3,10]. These four species (A. afra, A. аппиа, A. absinthium and A. abyssinica) are found in the Ethiopian flora [11,14]. They include glycosides, terpenes, alkaloids and essential oils [1].Three species were analyzed for comparison of essential oils of A. abyssinica, $A$. absinthium, and A. аппиа respectively. A. annua wondrous anti-malarial plant $[3,5,10]$ is native of Asia [3] and has been successfully introduced into many African countries including Ethiopia, Europe, America and Australia $[5,11,12]$. The major components in A. absinthium (Ariti) (Ethiopian Wormwood) essential oil are camphor and davanone $[7,11]$.

The essential oil has potential to be used in perfumery, cosmetics and aromatherapy and has been reported that it has an antifungal and antimicrobial effects [5]. A. absinthium. for which the botanists suggest the name "Ethiopian Wormwood", ( Ariti) is cultivated in home gardens in the Northern and Central Parts of Ethiopia. It is used to for its aroma at coffee ceremonies and in rituals called "Adbar" and for flavoring a locally distilled alcoholic drink called Areki. Artemisia abyssinica found on farm fields after harvest in Ethiopia is being used as a remedy for heart troubles and cough.

\section{Experimental, observations and discussion}

The areal part of A. abyssinica was collected from African Laboratory from Natural Products (ALNAP) garden. A. absinthium ( Ariti) and A. апnиa collected from local area. Fresh aerial parts of the three plants were crushed by liquid nitrogen. Each of the three powdered aerial parts of the plant material were subjected to hydro-distillation for $1 \frac{1}{2} \mathrm{~h}$, using a Clevenger-type apparatus.

Isolation of constituents of the essential oils was performed by column chromatography using silica gel (mesh: 70-230). Analytical TLC were run on a silica gel $60 \mathrm{~F}_{254}$ (Merck), 20 × $20 \mathrm{~cm}$ per coated plate and components were detected by spraying anisaldehyde reagent (anisaldehyde: $\mathrm{H}_{2} \mathrm{SO}_{4}$ : AcOH:EtOH ; 0.5:0.5:0.1:9) and further characterization by using ${ }^{1} \mathrm{HNMR}$ and ${ }^{13} \mathrm{CNMR}$ sophisticated techniques.

The identification and percentage composition of the essential oils was computed from GC and GC/MS peak areas. Qualitative analysis was based on comparison of retention times with the standard or isolated compounds and the corresponding data in the literature $[2,6,8,9] \mathrm{GC}$ analysis of the essential oils were performed using an instrument (Model: - HP6890 GC, coupled with an auto sampler) equipped with a capillary column HP-5 (5\%phenyl methyl siloxane), $30.0 \mathrm{~m}$ x $320 \mu \mathrm{m}$ i.d., film thickness $0.25 \mu \mathrm{m}$. Nitrogen was used as the carrier gas at a flow rate of $0.8 \mathrm{ml} / \mathrm{min}$. The oven temperature was held at $50{ }^{\circ} \mathrm{C}$, and then programmed to $210{ }^{\circ} \mathrm{C}$ at a rate of $3^{0} \mathrm{C} / \mathrm{min}$. The injection and FID temperatures were kept at $210{ }^{\circ} \mathrm{C}$ and $270{ }^{\circ} \mathrm{C}$, respectively.

The essential oils isolated by steam distillation of the areal parts of A. abyssinica, A. absinthium ( Ariti)and A. аппиа . Yield and color of the oils were summarized in Table-1. 
Table-1.

Percentage yield of essential oils of A. abyssinica, A. absinthium (Ariti) and A. annua.

\begin{tabular}{|l|l|l|l|l|}
\hline Plant & Wt. of plant material & Wt. of the Oil & Yield & Color of the Oil \\
\hline A. abyssinica & $45 \mathrm{~g}$ & $400 \mathrm{mg}$ & $0.9 \%$ & yellowish \\
\hline A. absinthium & $100 \mathrm{~g}$ & $460 \mathrm{mg}$ & $0.5 \%$ & Deep blue \\
\hline A. annua & $300 \mathrm{~g}$ & $144 \mathrm{mg}$ & $0.05 \%$ & greenish \\
\hline
\end{tabular}

The essential oils isolated from A. abyssinica were examined by GC and GC/MS. The results can be seen in Table-2. The components are listed in order of their elution on the HP-5 column. Chromatogram of the analysis is shown in appendix. The most compositions of the oil isolated around the first $20 \mathrm{~min}$ in GC/MS.

Table-2.

Percentage composition of the essential oil of $A$. abyssinica aerial parts.

\begin{tabular}{|l|l|l|}
\hline Compounds & $(\%)$ & Method of identification \\
\hline Yomogi alcohol & 32.2 & GC, GC/MS, NMR \\
\hline 1,8 -Cineole & 2.1 & GC/MS \\
\hline$\alpha$-Terpinene & 1.8 & GC/MS \\
\hline Nonanone & 6.4 & GC/MS \\
\hline Artemisia alcohol acetate & 26.7 & GC, GC/MS, NMR \\
\hline
\end{tabular}

Theessential oil of A. abyssinica contains the irregular monoterpenes yomogi alcohol (32\%) and artemisia alcohol acetate $(26.7 \%)$ as its major constituents. These two accounts $59 \%$ of the oil. The major peaks in the GC/MS spectra (at RT 12 and 18) indicate the presence of Yomogi alcohol and Artemisia alcohol acetate. Table-3 summarizes the major peak and the possible fragmented ion. The MS of the two compounds Yomogi alcohol and Artemisia alcohol acetate are shown in appendix. GC/MS Relative Intensity 10, Sensitivity $10^{-6} \mathrm{amps} / \mathrm{sec}$, First mass $1 \mathrm{amu}$, Last mass $300 \mathrm{amu}$, Integral start $40 \mathrm{amu}$, and Electron energy 70ev. Yomogi alcohol ( $\left.\mathrm{M}^{+} / \mathrm{e}: 154\right)$ Mass: 43, 59, 85, 121,136, 139, Relative intensity: 100, 84, 57, 29, 22, 5. Artemisia alcohol acetate $\left(\mathrm{M}^{+} / \mathrm{e}: 196\right)$ Mass: 85, 127, 137,153,182, Relative intensity: 100, 82, 68, 2. ( see appendix A,B and E )

Table-3

Major peaks and possible fragmented ions of Yomogi alcohol and Artemisia alcohol acetate.

\begin{tabular}{|l|l|l|l|}
\hline \multicolumn{2}{|l|}{ Yomogi alcohol } & Artemisia alcohol acetate & Fragmented ion \\
\hline Peak $(\mathrm{m} / \mathrm{z})$ & $\mathrm{M}-\left(\mathrm{CH}_{3}\right)$ & Peak $(\mathrm{m} / \mathrm{z})$ & $\mathrm{M}-\left(\mathrm{CH}_{3}\right)$ \\
\hline 139 & $\mathrm{M}-\left(\mathrm{H}_{2} \mathrm{O}\right)$ & 182 & $\mathrm{M}-\left(\mathrm{CH} \mathrm{CH}_{3}+\mathrm{CO}\right)$ \\
\hline 136 & $\mathrm{M}-\left(\mathrm{CH}_{3}+\mathrm{H}_{2} \mathrm{O}\right)$ & 153 & $\mathrm{M}-\left(\mathrm{CH}_{3}+\mathrm{CO}_{2}\right)$ \\
\hline 121 & $\left(\mathrm{CH}_{3}\right)_{2}-\mathrm{C}=\mathrm{OH}^{+}$ & 137 & $\mathrm{M}-\left(\mathrm{C}_{5} \mathrm{H}_{9}\right)$ \\
\hline 59 & ${ }^{+} \mathrm{O} \equiv \mathrm{C}_{-}-\mathrm{CH}_{3}$ & 85 & $(\mathrm{CH})_{2} \mathrm{C}=\mathrm{CH}-\mathrm{CH}=\mathrm{OH}{ }^{+}$ \\
\hline 43 & & & \\
\hline
\end{tabular}

The presence of Yomogi alcohol and Artemisia alcohol acetate was further checked by comparing their NMR data with literature values [6, 8, 9]. The two major components of A. Abyssinica were investigated more throughly by two- dimensional NMR-techniques in order to assign the ${ }^{1} \mathrm{H}$ and ${ }^{13} \mathrm{C}$ NMR spectra. The spectra obtained Table-4 ( see appendix F and G ) and Table -5. ( see appendix C and D )

Table-4 ${ }^{1}$ HNMR spectra of Yomogi alcohol. Table-5 ${ }^{1} \mathrm{HNMR}$ and ${ }^{13} \mathrm{CNMR}$ spectra of

\begin{tabular}{|c|c|c|c|c|}
\hline \multicolumn{5}{|c|}{ Artemisia alcohol acetate. } \\
\hline Position & ${ }^{1}$ HNMR Chemical shift, $\delta$ (ppm) & Position & $\begin{array}{l}{ }^{1} \text { HNMR Chemical shift, } \\
\delta(\mathrm{ppm})\end{array}$ & $\begin{array}{l}{ }^{13} \text { CNMR Chemical shift, } \\
\delta(\mathrm{ppm})\end{array}$ \\
\hline $1,3^{\prime}$ & 1.29 & 1 & 4.96 (trans) & 112.63 \\
\hline $2(\mathrm{OH})$ & 1.58 & 1 & 4.99 (cis) & 112.63 \\
\hline 3 & 5.57 & 2 & 5.84 & 144.22 \\
\hline 4 & 5.48 & 3 & - & 40.1 \\
\hline 5 & - & 4 & 5.3 & 76.47 \\
\hline 6 & 5.79 & 5 & 5.07 & 120.57 \\
\hline 7 & 4.90 (trans) & 6 & - & 137.15 \\
\hline 7 & 4.91 (cis) & 7,5 & 1.74 & 18.83 \\
\hline \multirow[t]{3}{*}{$1^{\prime}, 2^{\prime}$} & 1.09 & 1 ' & - & 169.57 \\
\hline & & 2 ' & 2 & 21.06 \\
\hline & & $3^{\prime}, 4^{\prime}$ & 0.99 & 22.14 \\
\hline
\end{tabular}


The percentage composition of the essential oils was computed from GC and GC/MS peak areas. Qualitative analysis was based on comparison of retention times with the standard or isolated compounds. [2, 6, $8,9]$. $1 \mathrm{~g}$ of the oil was separated on silica gel, which was successfully eluted with petroleum ether and $\mathrm{CH}_{2} \mathrm{Cl}_{2}$. 30 fractions were collected.

\section{1. Yomogi Alcohol}

Fractions 19 to $28(100 \mathrm{mg})$ were combined after chromatographed on a column of silica gel, mixtures of petrol- $\mathrm{CH}_{2} \mathrm{Cl}_{2}$ in the ratio (1:1) as eluent solvent. This was identified as Yomogi alcohol: ${ }^{1} \mathrm{HNMR}(400 \mathrm{MHz}$, $\mathrm{CDCl}_{3}$ and $\left.\mathrm{CD}_{4}\right): \delta 1.09\left(6 \mathrm{H}, \mathrm{s}, 1^{\prime}-\mathrm{CH}_{3}, 2^{\prime}-\mathrm{CH}_{3}\right), 1.29\left(6 \mathrm{H}, \mathrm{s}, 1-\mathrm{CH}_{3}, 3^{\prime}-\mathrm{CH}_{3}\right), 1.58(1 \mathrm{H}, \mathrm{s}, 2-\mathrm{OH}), 4.90(1 \mathrm{H}, \mathrm{d}$, 7- $\mathrm{CH}_{2}$ trans), $4.91\left(1 \mathrm{H}, \mathrm{d}, 7-\mathrm{CH}_{2} \mathrm{cis}\right), 5.48(1 \mathrm{H}, \mathrm{d}, 3-\mathrm{CH}), 5.47(1 \mathrm{H}, \mathrm{d}, 4-\mathrm{CH}), 5.79(1 \mathrm{H}, \mathrm{dd}, 6-\mathrm{CH})$ ( see appendix $\mathrm{F}$ and $\mathrm{G}$ ).

\section{2. Artemisia Alcohol Acetate}

The combined fractions 11 to $15(160 \mathrm{mg})$ from CC contained the light yellow component and gave a single spot on TLC. This was identified as Artemisia alcohol acetate on the basis of its spectra: ${ }^{1} \mathrm{HNMR}$ (400 $\mathrm{MHz}, \mathrm{CDCl}_{3}$ and $\left.\mathrm{CD}_{4}\right): \delta 0.99\left(6 \mathrm{H}, \mathrm{s}, 3^{\prime}-\mathrm{CH}_{3}, 4^{\prime}-\mathrm{CH}_{3}\right), 1.74\left(6 \mathrm{H}, \mathrm{s}, 5{ }^{\prime}-\mathrm{CH}_{3}, 7-\mathrm{CH}_{3}\right), 2.00\left(3 \mathrm{H}, \mathrm{s}, 2^{\prime}-\mathrm{CH}_{3}\right), 4.96$ $\left(1 \mathrm{H}, \mathrm{d}, 1-\mathrm{CH}_{2}\right.$ trans), $4.99\left(1 \mathrm{H}, \mathrm{d}, 1-\mathrm{CH}_{2} \mathrm{cis}\right), 5.02(1 \mathrm{H}, \mathrm{d}, 5-\mathrm{CH}), 5.29(1 \mathrm{H}, \mathrm{d}, 4-\mathrm{CH}), 5.84(1 \mathrm{H}, \mathrm{dd}, 2-\mathrm{CH}) .(\mathrm{see}$ appendix $\mathrm{C}$ and $\mathrm{D}$ )<smiles>C=CC(C)(C)[C@H](CC=C(C)C)OC(C)=O</smiles>

Artemisia alcohol acetate<smiles>C=CC(C)(C)/C=C/C(C)(C)O</smiles>

Yomogi alcohol

The essential oils obtained from A. absinthium ( Ariti) and A. annua were also analyzed by GC. Constituents of the oils were identified by using RT and NMR. The identified components account for $44 \%$ and $56 \%$ of the oils of $A$. апnиа and A. absinthium (Ariti), respectively. Both oils were composed of camphor as a major constituent and account for $44 \%$ and $41 \%$ of the oil of A. annua and A. absinthium (Ariti) respectively.Chamazulene $(0.6 \%$ ) and Davanone (14\%) were isolated from A. absinthium (Ariti) by CC and identified on the bases of their spectra ${ }^{1} \mathrm{HNMR}$ and ${ }^{13} \mathrm{CNMR}$. The spectra obtained were identical with literature values Table-6 ( see appendix H ) and Table -7 ( see appendix I ) [7].

Table -6 ${ }^{1}$ HNMR spectra of chamazulene.

Table $-7{ }^{1}$ HNMR spectra of davanone.

\begin{tabular}{|c|c|c|c|}
\hline Position & ${ }^{1}$ HNMR Chemical shift, $\delta(\mathrm{ppm})$ & Position & ${ }^{1}$ HNMR Chemical shift, $\delta$ (ppm) \\
\hline 3 & 6.9 & 1 & 5.19 (cis) \\
\hline 4 & 7.38 & 1 & 4.98 (trans) \\
\hline 6 & 8.14 & 2 & 5.88 \\
\hline 9 & 7.2 & 6 & 3.26 \\
\hline 10 & 7.6 & 7 & 2.68 \\
\hline $1 '$ & 2.87 & 12 & 1.64 \\
\hline 2 ' & 1.38 & $1^{\prime}$ & 1.27 \\
\hline 3 ' & 2.67 & 2 ' & 0.99 \\
\hline 4, & 2.85 & 3 & 1.77 \\
\hline
\end{tabular}

\section{3. Isolation of Compounds from A. absinthium ( Ariti)} were collected.

$400 \mathrm{mg}$ of the oil was packed on column and eluted with petroleum ether and $\mathrm{CH}_{2} \mathrm{Cl}_{2} .30$ fractions

\section{3. 1. Chamazulene}

The combined fractions 6 to 8 (46 mg) from CC contained the blue component and gave a single spot on TLC. This was identified as Chamazulene based on its spectra: ${ }^{1} \mathrm{HNMR}\left(400 \mathrm{MHz}, \mathrm{CDCl}_{3}\right.$ and $\left.\mathrm{CD}_{4}\right): \delta 1.38$ $\left(3 \mathrm{H}, \mathrm{t}, 2^{\prime}-\mathrm{CH}_{3}\right), 2.67\left(3 \mathrm{H}, \mathrm{s}, 3^{\prime}-\mathrm{CH}_{3}\right), 2.85\left(3 \mathrm{H}, \mathrm{s}, 4^{\prime}-\mathrm{CH}_{3}\right), 2.87\left(2 \mathrm{H}, \mathrm{q}, 1\right.$ ' $\left.-\mathrm{CH}_{2}\right), 6.90(1 \mathrm{H}, \mathrm{d}, 3-\mathrm{CH}), 7.20(1 \mathrm{H}$, d, 9-CH), $7.38(1 \mathrm{H}, \mathrm{dd}, 4-\mathrm{CH}), 7.60(1 \mathrm{H}, \mathrm{d}, 10-\mathrm{CH}), 8.14(1 \mathrm{H}, \mathrm{d}, 6-\mathrm{CH})$. (see appendix $\mathrm{H}$ )

\section{3. 2. Davanone}

Fractions 25, 26 and 27 were combined after chromatographed on a column of silica gel and petrolEtOAc (8:2) solvent system, which was, identified as Davanone based on its spectra. ${ }^{1} \mathrm{HNMR}\left(400 \mathrm{MHz} \mathrm{CDCl}_{3}\right.$ 
and $\left.\mathrm{CD}_{4}\right): \delta 0.99\left(3 \mathrm{H}, \mathrm{d}, 2^{\prime}-\mathrm{CH}_{3}\right), 1.27\left(3 \mathrm{H}, \mathrm{s}, 1^{\prime}-\mathrm{CH}_{3}\right), 1.64\left(3 \mathrm{H}, \mathrm{s}, 12-\mathrm{CH}_{3}\right), 1.77\left(3 \mathrm{H}, \mathrm{s}, 3^{\prime}-\mathrm{CH}_{3}\right), 2.68(1 \mathrm{H}$, qn, 7-CH), $3.26(1 \mathrm{H}, \mathrm{qd}, 6-\mathrm{CH}), 4.98(1 \mathrm{H}, \mathrm{dd}, 1-\mathrm{CH}$ trans $), 5.19(1 \mathrm{H}, \mathrm{dd}, 1-\mathrm{CH}$ cis $), 5.88(1 \mathrm{H}, \mathrm{dd}, 2-\mathrm{CH})$.

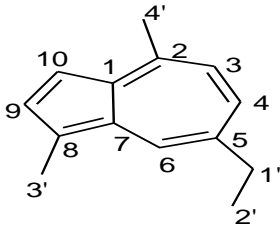

Chamazulene<smiles></smiles>

Devanone

\section{Conclusions}

The chemical constituent of $A$. abyssinica has not reported yet.However, several analyses [3, 4, 5, 7, 13] have done for the oils of A. апnиa and Ariti. The two major components of the oil of A. abyssinica are yomogi alcohol and artemisia alcohol acetate and both them are irregular monoterpenes.

Even though the botanists lumped Ariti together with the well-known species A. absinthium, their chemical constituents shows some deviation. In the oil of Ariti (Ethiopian wormwood) we have found that camphor and davanone as a major components. However, thujone is the major component for the European wormwood. Therefore, it requires further investigation before mixing the two species.

\section{Appendix (A)}

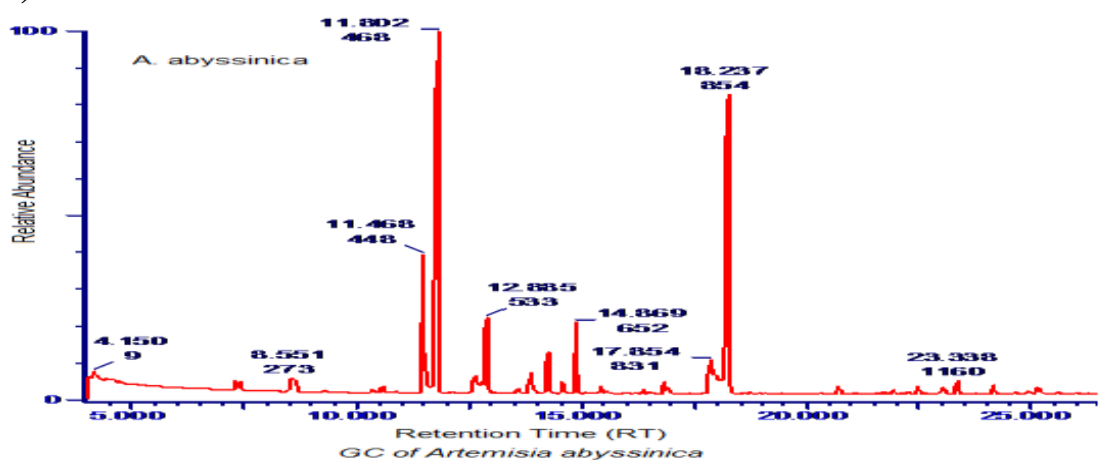

Appendix (B)

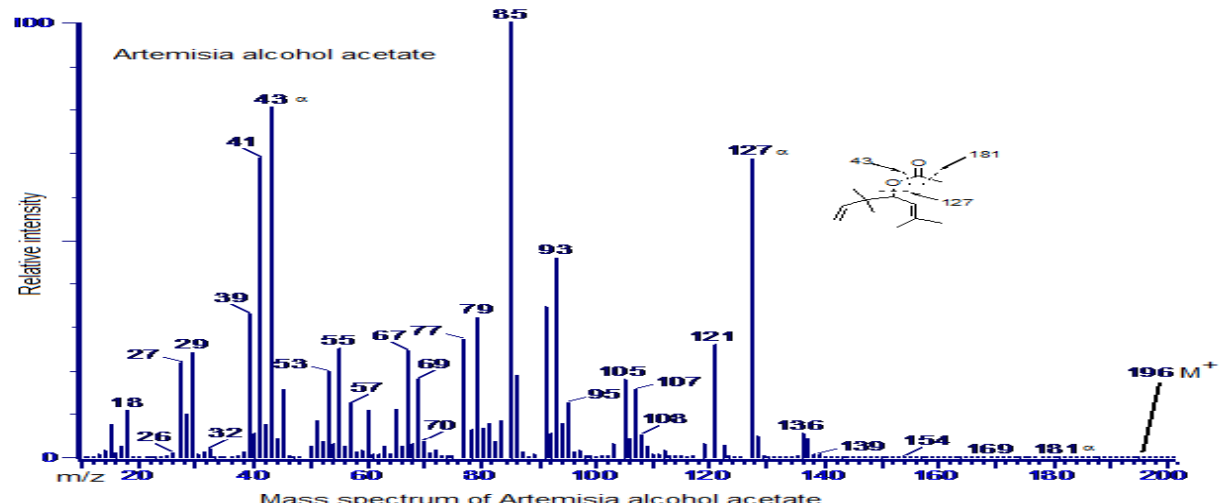

Appendix (C)

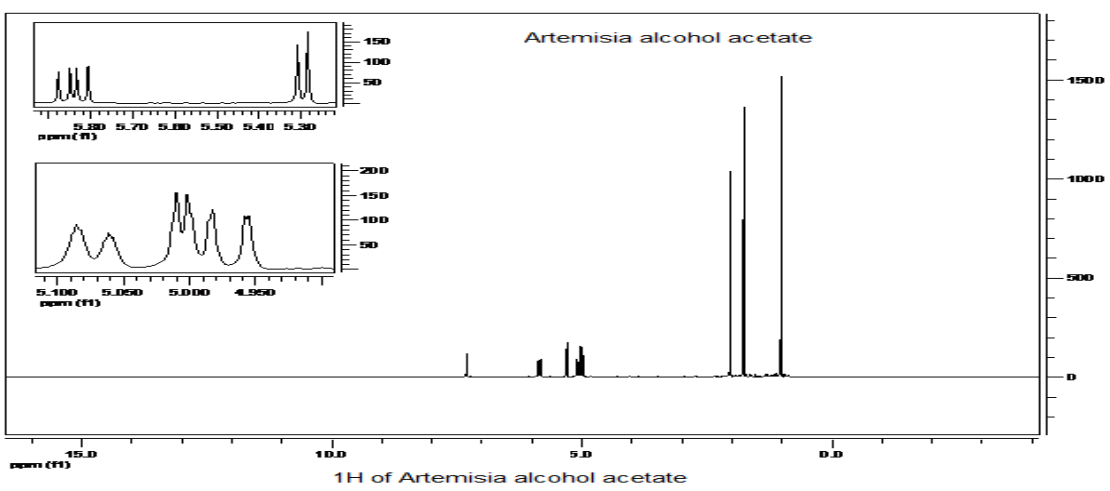




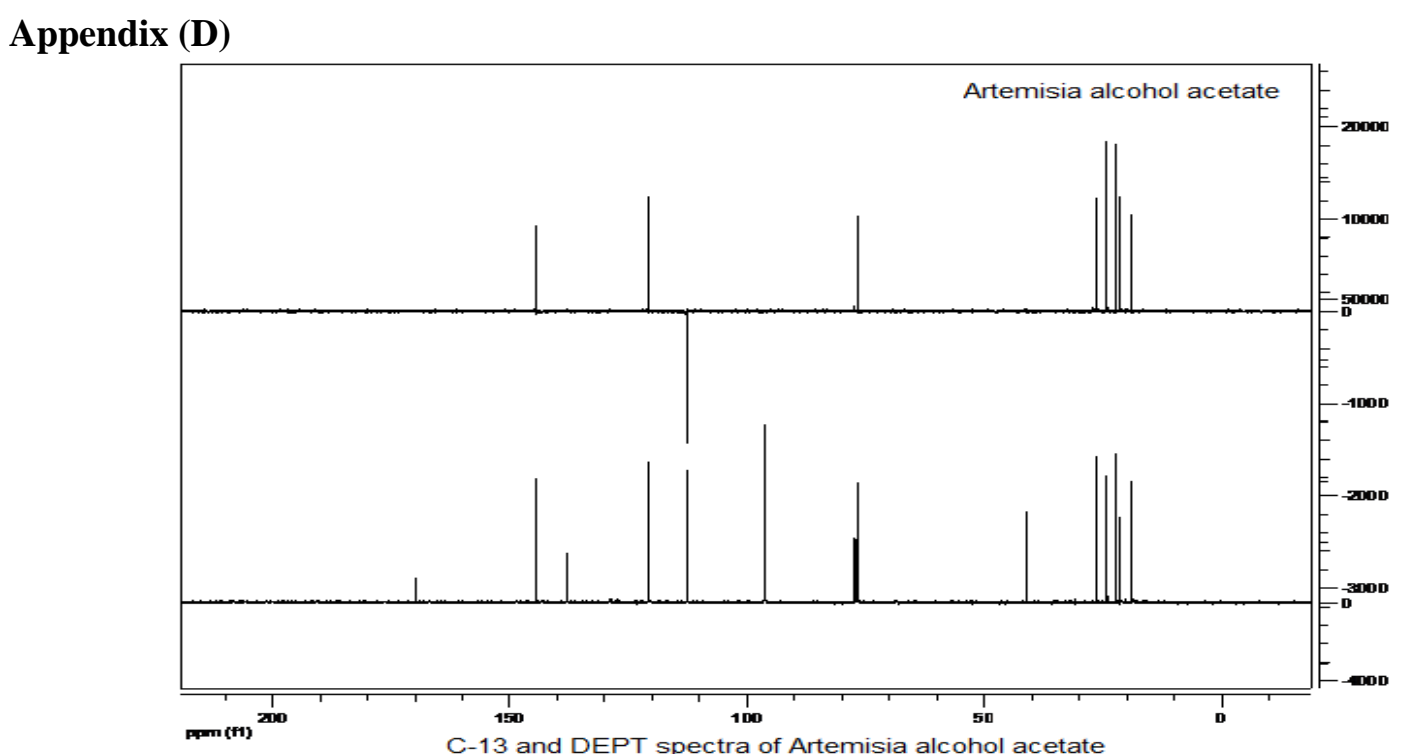

\section{Appendix (E)}

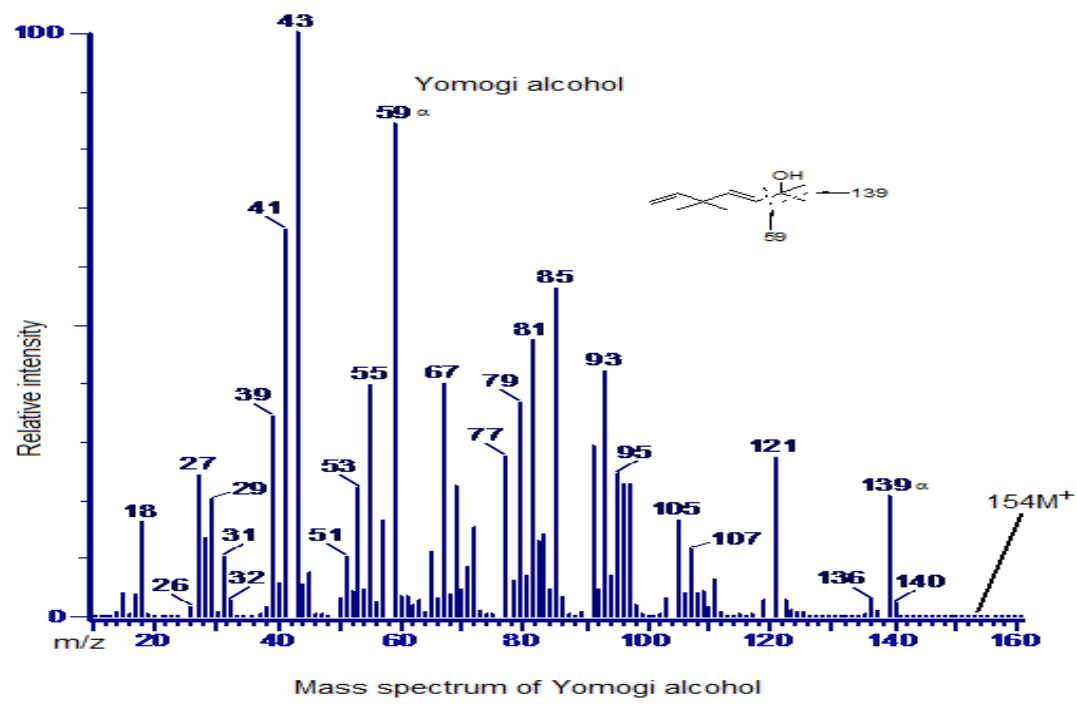

\section{Appendix (F)}

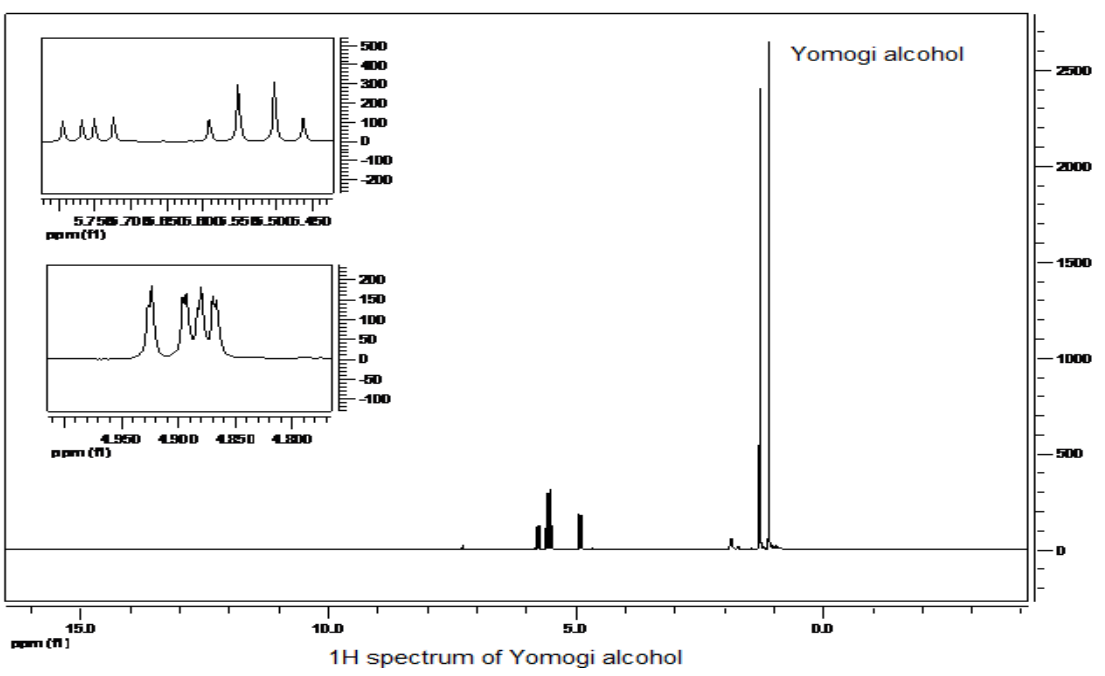




\section{Appendix (G)}

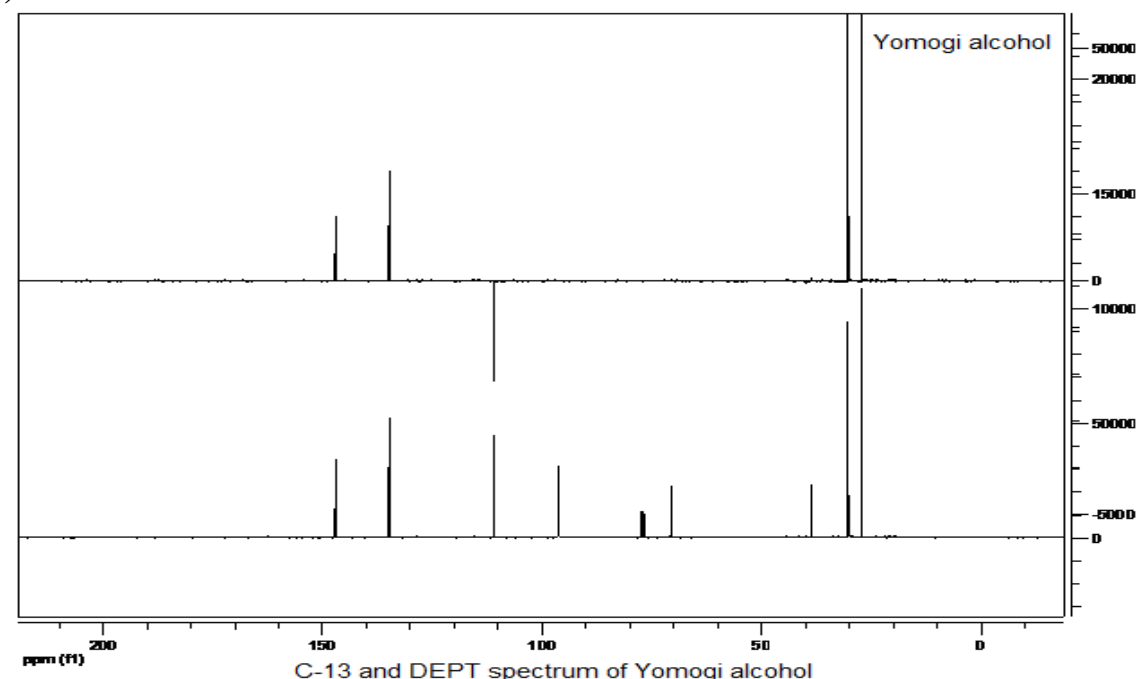

Appendix (H)

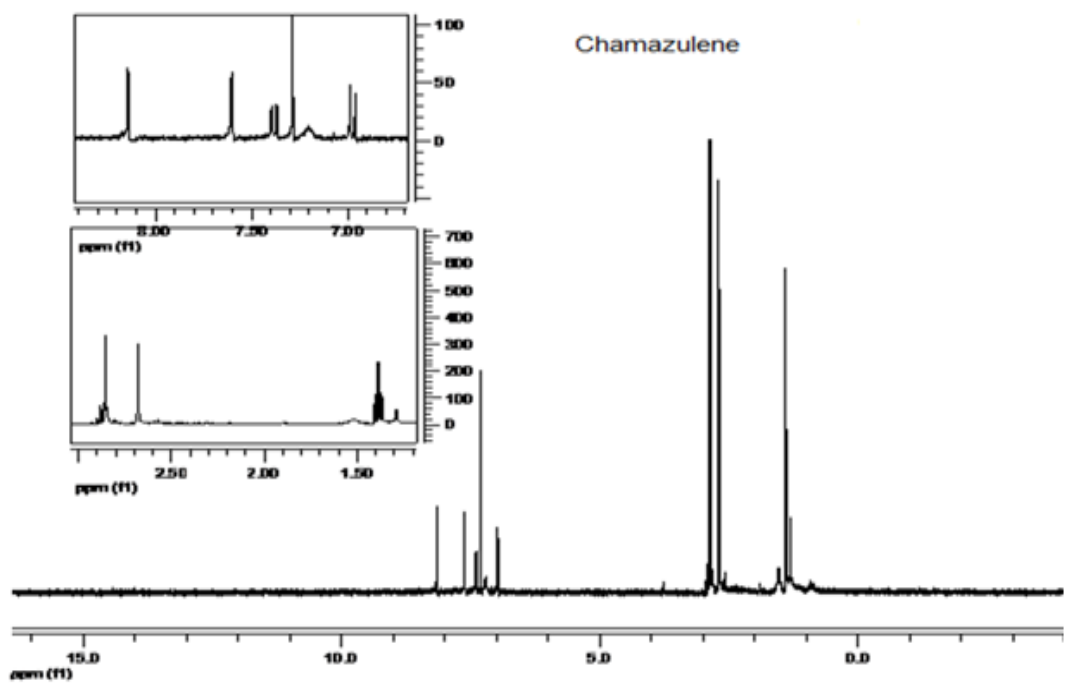

${ }^{1} \mathrm{HNMR}$ of chamazulene

Appendix (I)

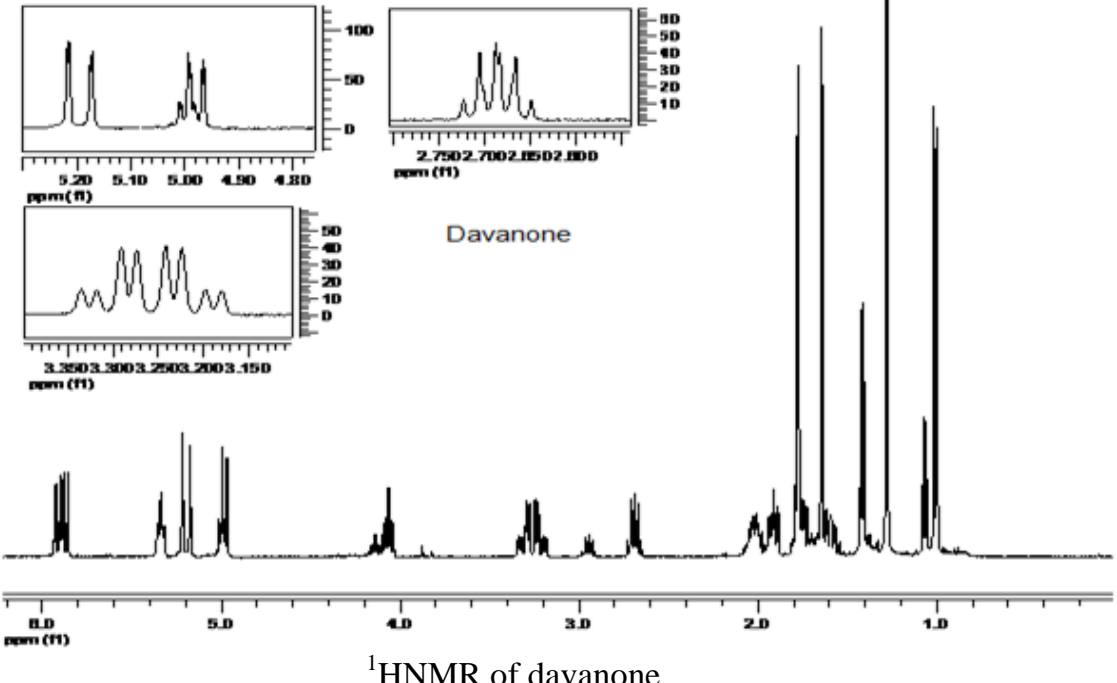




\section{References}

[1]. http://www.essential-oil.org/essential_oilcomponents.asp

[2]. http://www.ics.trieste.it/MAPs/EssentialOils_Compound.aspx?id=4

[3]. M.R. Verdian-rizi, E. Sadat-Ebrahimi, A. Hadjiakhoondi, M.R. Fazeli and P. Hamedani, Chemical Composition and Antimicrobial Activity of Artemisia annua L. Essential Oil from Iran, Journal of Medicinal Plants, 7 (4), 2008, 123-127

[4]. G. Brown, G. Liang and L. SY, Terpenoids from the Seeds of Artemisia annua, Phytochemistry, 64, 2003, 303-323

[5]. S. Khangholil, and A. Rezaeinodehi, Effect of Drying Temperature on Essential Oil Content and Composition of Sweet Wormwood (Artemisia annua) Growing Wild in Iran, Pak. J. Biol. Sci., 11 (6), 2008, 934-937

[6]. B. Abegaz and W. Herz, A Non-Monoterpene from Artemisia schimperi, Phytochemistry, 30, 1991, 1011-1012

[7]. B. Abegaz and G. Yohannes, Constituents of the Essential Oil of Artemisia rehan, Phytochemistry, 21 (7), 1982, 1791-1793

[8]. C. Dale and M. John, Model Studies of Biosynthesis of Non-Head-to-Tail Terpenes. Stereochemistry of Ionization for N-Methyl-4[(1S,1'R,3'R)-[1-²H]chrysanthe- myloxy] -pyridinium Iodide, J. Am. Chem. Soc., 99, 1977, 3824-3829

[9]. C. Dale and M. John, Model Studies of Biosynthesis of Non-Head-to-Tail Terpenes, stereochemistry of the head-to-head Rearrangement, J. Am. Chem. Soc., 99, 1977, 3830-3837

[10]. J. Leland, B. Peter, L. Sara, A. James and L. Herry, Natural Products from Plants $2^{\text {nd }}$ edition, 2006, 10- 11

[11]. ALNAP Phytochemical Database.

[12]. M. Dewick, MedicinalNatural Products, a Biosynthetic Approach, $2^{\text {nd }}$ edition, 2002, 198-200

[13]. A. Judpentiene and D. Mockute, Chemical Composition of Essential Oils of Artemisia absinthium L. (wormwood) Growing Wild in Vilnius, Chmija, 15 (4), 2004, 64-68

[14]. Flora of Ethiopia and Eritrea., 4 (2), 221-224 